\title{
Politicised nexus thinking in practice: Integrating urban wastewater utilities into regional energy markets
}

Urban Studies

2019, Vol. 56(II) 2225-224I

(c) Urban Studies Journal Limited 2017

Article reuse guidelines:

sagepub.com/journals-permissions

DOI: $10.1177 / 0042098017735229$

journals.sagepub.com/home/usj

@SAGE

\section{Timothy Moss}

Humboldt University of Berlin, Germany

\section{Frank Hüesker}

Technical University of Kaiserslautern, Germany

\begin{abstract}
Infrastructures are key interfaces of urban resource use, connecting production to consumption, cities to their hinterland and energy to water and land use. They have, however, received scant attention in debates on nexus thinking in general, and the urban nexus in particular. Drawing on an emergent critical literature on the nexus in urban studies and science and technology studies, this article examines practices of (attempted) inter-sectoral infrastructure integration at the interface of urban wastewater treatment and regional energy provision in Germany. It analyses the nexus approaches and experiences of eight German cities / city-regions as so-called 'flexibility providers' in regional energy markets for electricity, gas and heating. It demonstrates how the practices of wastewater utilities operating in energy markets involve far more than technical adaptation, requiring in addition a major reordering of existing material, spatial and institutional configurations to both wastewater and energy systems. This is proving a deeply political process with important implications for our understanding of socio-technical transitions at the water-energy nexus.
\end{abstract}

\section{Keywords}

local politics, nexus, renewable energy, urban infrastructure, wastewater

\begin{abstract}
摘要
基础设施是城市资源利用的关键连接口，将生产连接至消费，城市连接至内陆腹地，能源连接 至水和土地利用。然而, 在学界总体关于 “关系” (nexus) 思维和具体关于城市关系的讨论中, 基础设施鲜受关注。本文借鉴城市研究和科技研究中新涌现出的关于 “关系” 的关键文献，考 察了德国城市污水处理与区域能源供应交接地带的部门间基础设施整合实践。我们选取了德国 八个在电力、燃气和暖气供应的区域能源市场中以所谓 “灵活供应商” 身份出现的城市/城市地 区，分析了其 “关系” 进路和经历。分析表明，在能源市场运行的污水处理设施，其所做远远 不止是技术调整适应, 另外还要对废水和能源系统的现有材料、空间和机构配置进行大幅重整。 研究证明, 这是一个深远的政治进程, 对我们理解水能源关系中的社会技术转型具有重要意义。
\end{abstract}

关键词

地方政治、联系、可再生能源、城市基础设施、废水 


\section{Introduction}

Integration is in. Not for the first time in the history of urban metabolism, greater interconnectivity is being proclaimed as an answer to growing complexity, negative externalities and technological diversity. Today's buzz word is nexus. Coined as currently used at the World Economic Forum in 2008 to capture the interdependencies between energy, water and - subsequently - food provision (World Economic Forum, 2011), it has risen to become a global paradigm for securing access to, control over and use of essential natural resources that is now cited widely in international programmes for sustainable development (Allouche et al., 2015). The initial focus on the water-energy nexus has since mutated to encompass a broad array of themes, including the urban nexus. What exactly is meant by urban nexus is not always clear: the literature uses the term diversely to address the waterenergy-food nexus in cities, integrated approaches to urban metabolism but also urban-rural relations. Curious to studies of the water-energy nexus in cities is the general absence of urban infrastructure in the analysis. As the guest editors, Jochen Monstadt and Olivier Coutard, posited in their proposal for this special issue, infrastructures are key interfaces of urban resource use, connecting production to consumption, cities to their hinterland and energy to water and land use. Yet the proverbial 'invisible city' of underground pipes and technical appliances which transport and transform energy, water and wastewater for human settlements is rarely centre stage in nexus studies. More than this, the major advances in understanding urban infrastructures as dynamic, relational and sociotechnical configurations - thanks to recent work at the interface of urban studies and science and technology studies - have largely eluded scholarship on the nexus.

It is with this in mind that this article analyses early steps to promote nexus practices between urban energy and wastewater infrastructures in the wake of Germany's ongoing energy transition. As pressure mounts to find effective ways of integrating the rapid growth of renewable electricity, especially from fluctuating sources (wind power, photovoltaics), into transmission and distribution grids across the country, we study initial steps taken by municipal wastewater utilities to use their treatment facilities as flexibility providers for (regional) energy markets. These include electricity storage with power-to-gas technology when electricity from renewables is high, load management of the grid when electricity from renewables is low and feeding gas or heat into local distribution networks (BEE, 2015). We present and discuss fresh empirical data on the nexus approaches and experiences to date of a range of German cities (including Berlin, Hamburg and Cologne) that are considering or practising such forms of inter-sectoral integration at the interface of urban wastewater treatment, regional energy distribution and municipal utilities. This article illustrates the various ways in which Germany's wastewater utilities are trying to translate their nexus aspirations into practice and discusses these as a contribution to infrastructure integration. By targeting inter-sectoral and urban-regional relations, we address two blind spots in recent scholarship on urban infrastructures: the socio-technical connectivity of energy and wastewater systems and the regional contexts of urban energy transitions.

We begin by reflecting on how infrastructure coupling has (or has not) been 
addressed in the relevant literatures namely in work on the water-energy nexus, the resource-efficient city and urban infrastructure transitions - identifying key research gaps and providing conceptual orientation for the study. The empirical analysis that follows is divided into three parts. We initially set out the political framework for municipal wastewater utilities to become integrated into energy markets in Germany and their approaches to act as prospective regional energy managers. We then present current experiences of cities promoting infrastructural co-management. We finally interpret the data in terms of four dimensions of infrastructure integration: materiality, spatiality, temporality and politics. In the concluding section we summarise the findings, highlighting key messages on reconfiguring urban infrastructures along more nexus-oriented lines.

\section{Infrastructure coupling for the resource-efficient city}

Nexus thinking is a way of highlighting interconnectivity between water, food and energy provision in order to reduce negative trade-offs and generate co-benefits for sustainable development (Stein et al., 2014). Calls for policy integration have come in many guises over the years, notably under the banners of Integrated Water Resources Management (IWRM) and Integrated Natural Resources Management (INRM) (Jensen, 2013). The nexus, with its claim to cross-sectoral integration, promises of winwin solutions and attention to resource security issues, has been attracting an even broader range of interest in policy and research circles in recent years. Its appeal lies, essentially, in its suggestive power that better knowledge of connectivity will lead to more integrated policies, which will in turn generate more sustainable resource use overall (Cairns and Krzywoszynska, 2016).
A consortium of leading global change scholars recently identified urbanisation and the resource nexus as one of three overarching global change problems (Brondzio et al., 2015). Seeing the city as a prime site for complex interactions across resource systems affecting demand for land, water and energy, environmental and engineering scientists are setting out to capture the relationship between different resource flows. They are drawing on concepts of life cycle assessment (Nair et al., 2014), integrated assessment (Hake et al., 2016), input-output analysis (Chen and $\mathrm{Lu}, 2015$ ) and multi-sectoral systems analysis (Walker et al., 2014) in order to model interdependencies between urban resource flows. Rather than focusing on one resource (e.g. water) only, these 'urban nexus' approaches are considered as 'a useful metaphor to investigate mutual dependency of multiple elements in terms of coupled material and energy flows being interlinked and conversion processes embedded in intertwined chains at multiple scales in order to achieve a sustainable city' (Chen and Lu, 2015: 5). Specifically relating to water and energy, these studies aspire to quantify water use in energy production and, vice versa, energy use in water treatment and provision in order to support decision-making for policy, planning and investment (Chen and Chen, 2016; Venkatesch et al., 2014). The underpinning assumption is that with this new knowledge inefficient resource use can be targeted, potential synergies revealed and management concepts optimised in the interest of sustainable urban development.

This technical literature has come in for some criticism for oversimplifying - or, indeed, overlooking - institutional and policy dimensions of the energy-water nexus (Stein et al., 2014). The nexus cannot be reduced to resource efficiency alone, it is argued here, but needs to address the institutional opportunities and impediments involved in cross-sectoral and multi-tier 
decision-making and management (Scott et al., 2011). Acknowledging the degree of policy fragmentation common between the water and energy sectors, Hussey and Pittock warn against easy solutions but rephrase the problems as a challenge for policymakers and industry 'to develop policies, processes, and analytical tools that integrate the energy-water nexus (and related issues such as food security) into policy and investment decisions' (Hussey and Pittock, 2012: 31).

Williams et al. (2014) go further in their criticism, challenging the notion underpinning much of this literature that better integration necessarily means more sustainable resource management. Nexus thinking, they argue, has so far been directed at resolving techno-managerial challenges, rather than tackling the deeper contradictions and contestations that characterise water and energy consumption. This involves acknowledging the political nature of the nexus and the techno-political processes by which its components are coproduced as context-specific and multi-scalar 'nexus assemblages' (Williams et al., 2014: 2). They call for more work politicising the water-energy nexus (cf. Stirling, 2014), but also unpacking the multiple geographies of nexus. This includes the role of cities in producing or reconfiguring nexus interactions.

One might expect urban infrastructures to play a key role in these studies of the water-energy nexus. This, curiously, is not the case: 'Despite huge interest in issues of sectoral integration surrounding the waterenergy nexus, researchers have rarely considered what this might mean for the coupling of infrastructure systems for water/wastewater and energy services' (Moss et al., 2017: 269). Conversely, within the growing social science literature on urban infrastructures few studies have targeted connectivity between two or more infrastructure sectors. One such example is Hodson and Marvin's
(2010) study of 'integrated eco-urbanism', exploring how multiple infrastructure networks are being rebundled at particular scales and in different ways - for instance, eco-cities, eco-islands or transition towns as urban responses to enhance ecological security. A second is an article by Moss et al. (2017) on a failed attempt to couple wastewater and energy infrastructures in order to use treated wastewater for energy crop production, revealing crucial institutional and spatial incompatibilities. A third is work on 'smart' technologies and cities which more frequently targets infrastructure interfaces in the form of ICT-mediated urban networks (e.g. Luque, 2014).

What recent sociotechnical research on urban infrastructures can contribute is powerful analytical categories with which to interrogate interactions between infrastructures and cities, between nature and the city and between production and consumption. The journal Urban Studies has been a prominent vehicle for these debates, notably with the special issue guest edited by Rutherford and Coutard (2014). Four categories have been selected to guide the research and analysis of this article that resonate with the overarching themes of this special issue:

1. The socio-materiality underpinning processes of socio-technical reassembling. This draws on scholarship explaining how infrastructures act as 'material mediators between nature and the city' (Kaika and Swyngedouw, 2000: 120) in processes of metabolic circulation (Monstadt, 2009).

2. The multiple spatialities at play in reconfiguring infrastructures. These relate to the scalar and place-based geographies involved in reconfiguring socio-technical systems (Coenen et al., 2012), such as how cities shape, and are shaped by, urban infrastructures (Gandy, 2004) or how spatial disparities can be 
exacerbated by the liberalisation, privatisation and commercialisation of utilities (Graham and Marvin, 2001).

3. The complex temporalities that need aligning when connecting wastewater and energy systems. Research points, for instance, to the ways in which sociotechnical innovations are embedded in complex urbanisation processes (Melosi, 2000) and urban energy transitions co-evolve along non-linear pathways (Bulkeley et al., 2011).

4. The politics of infrastructure coupling. Recent scholarship has sensitised us to the importance of politics in sustainability transitions (Meadowcroft, 2009), for instance the power relations between incumbent grid operators and new market players and the (dis)incentives posed by institutional arrangements.

\section{Urban nexus imaginaries: Political framework, technologies and approaches}

\section{Political framework for regional energy markets and flexibility providers}

Germany's energy transition has, to date, succeeded in boosting the share of renewables in electricity generation. However, $\mathrm{CO}_{2}$ emissions rose again in 2016 and Germany's revised energy policy of 2017 does not actively address some major challenges, such as the local integration of intermittent renewable energy into the power grids (Quitzow et al., 2016). As technological innovation in the energy sector and digitalisation advance apace, concerted political efforts are needed to reorder institutional arrangements for the country's energy grids and markets. If grid expansion is not to be the only solution, many progressive actors argue that so-called flexibility options (e.g. load management, storage, power-to-gas) need to be developed for a future with less nuclear and fossil energy, but are currently under-developed (Deutsche Energieagentur, 2014, 2017).

Whilst most of Germany's new renewable energy from wind power, biomass and solar power is generated in rural areas, it is the cities where energy use is concentrated. This raises the question of what role cities can play in advancing Germany's energy transition. Key to this is finding resource-efficient ways of dealing with massively growing, intermittent flows of renewable energy, developing technologies, political strategies and business models for flexibility providers. Balancing electricity flows in grids and markets needs to be conducted locally, at least in part, owing to the decentralised nature of electricity generation from renewables. This calls for new regional energy markets (Agora Energiewende, 2017).

In the past, and still today, balancing electricity flows in Germany is mainly the responsibility of the four privately run and strongly regulated transmission grid operators. The balancing market is conducted primarily on the transmission scale. Several hundred distribution grid operators manage loads according to the needs of the transmission grid.

Municipalities, rural and urban, are free to act in all stages of the electricity provision system, from generation to transmission, distribution and supply. Municipalities and their utilities can own and operate infrastructures for heating, gas, electricity and wastewater. Where ownership and responsibility are combined in multi-utility Stadtwerke, municipalities have greater potential to engage in cross-sectoral practices, for instance at the wastewater-energy nexus. Where this organisational integration is coupled with a political will to engage in the energy transition, cities can become involved in developing a regional energy market, drawing on existing infrastructure and investing in smart grids in order to act as a 
generator and wholesaler of regional electricity. By a regional energy market we mean one in which local generation, consumption, distribution and storage are organised on a regional scale. Moving from the urban to the regional scale of energy markets is, however, far from straightforward for municipalities. As several municipal wastewater utilities have experienced recently, the relevant regulatory framework is complex when it comes to acting beyond municipal boundaries and across sectors, and powerful incumbent actors - notably the grid operators - are reluctant to concede market space to newcomers. The task is revealed to be highly political, requiring politicised nexus thinking and practice.

\section{Technical options}

Wastewater utilities are highly significant for energy provision and use for two reasons. On the one hand, they use huge amounts of energy, being often the largest single electricity consumer in a city. On the other hand, the wastewater they process contains significant quantities of energy in many different physical and chemical forms. As energy efficiency and climate change protection have recently risen up the policy agenda in Germany, wastewater utilities are being called upon to reduce energy consumption and explore uses for their own renewable energy sources. In 2015, according to the German Federal Statistical Office, ca. 1.4 million megawatt-hours of electricity was generated from sewage gas. Currently only around $7.5 \%$ of this is fed into power grids, with the remaining $92 \%$ being used by the wastewater treatment plants themselves (www.genesis.destatis.de).

Here, we are less interested in techniques to increase self-sufficiency in energy provision internally than in ways of integrating energy from wastewater treatment plants into regional or even trans-regional energy markets. Thus we only acknowledge in passing that many wastewater utilities generate electricity for their own use by fermenting sewage sludge into biogas and transforming this via combined heat-and-power units into (renewable) electricity and heat. Wastewater utilities can become active instruments of urban energy policy not simply by selling home-grown electricity to the grid, but in helping balance electricity fed into, and drawn from, the grid by means of adapted wastewater treatment processes or power-togas technologies (Seidl, 2016). Wastewater utilities possess two strategic advantages that enable them to provide additional flexibility to energy networks. Firstly, the principal source of energy in their treatment processes - biomass in the form of sewage sludge - is not dependent on fluctuating wind or sunshine and can be provided in relatively constant quantity. Secondly, wastewater utilities have the potential to store energy in various ways, particularly in gas form as purified sewage gas, hydrogen or synthetic gas, which can subsequently be transformed back into electricity and heat that can be fed into regional energy networks. This means they have the potential to act favourably on the load management of regional power grids and to help balance out the volatility of electricity feed-in from other renewable energy sources such as wind power and photovoltaics, thereby minimising the risk of overloading the grid (Umweltbundesamt, 2016).

\section{Nexus approaches of actors}

The purpose of this article is to examine the approaches, experiences and prospects for urban wastewater utilities to play an active role in regional energy markets, analysing the opinions of diverse leading actors in the wastewater and energy sectors. The principal data source is 21 semi-standardised interviews conducted between 2015 and 2016 with the following relevant stakeholders 
operating at the wastewater-energy nexus (see Appendix A1), as follows:

- eight interviews with some of the largest urban wastewater utilities in Germany (mainly managers from environmental/ energy departments), covering three major cities (Berlin, Hamburg and Cologne), three medium-sized cities (Mainz, Kaiserslautern and Bremen) and two water boards from urban, industrialised river basins (Wupperverband and Emschergenossenschaft/Lippeverband);

- five interviews with the main relevant national lobbying associations: for municipal companies (Verband Kommunaler Unternehmen); municipal politics (Deutscher Städte- und Gemeindebund); renewable energies (Bundesverband Erneuerbare Energien); the water, wastewater and waste sector (Deutsche Vereinigung für Wasser, Abwasser und Abfall); and the energy and water sector (Bundesverband der deutschen Energieund Wasserwirtschaft);

- officials from the three relevant political levels: state level (environmental ministry of Rhineland Palatinate), federal level (German Ministry for Economy and Energy) and European level (Directorate General Energy);

- four pro-active actors from the energy sector (a grid operator, the energy agency of Northrhine Westphalia, a local multiutility and a power trader).

These interviews are complemented by three stakeholder workshops on the topic organised by the authors in 2015 and 2016, as well as the (limited) literature and documents available to date.

The approaches taken by the cities studied in response to the political framework and technical options for using wastewater utilities as flexibility providers in regional energy markets vary considerably. We can, for instance, observe differences between cities where urban wastewater utilities and local politics have traditionally cooperated closely (e.g. Hamburg, Cologne and Kaiserslautern) and those where the wastewater utilities act largely independent of urban policy (e.g. Berlin, Mainz and Bremen). Broadly, we could identify three types of nexus approaches in city governments and wastewater utilities.

Firstly, the most common type of nexus thinking is, at its core, motivated by economic feasibility. The vision here is founded on the wastewater utility's dual role as energy producer and consumer (prosumer). The main aim of this techno-managerial strategy is to maximise self-consumption of the energy generated, providing or exceeding $100 \%$ of its own consumption. This type of managerial nexus thinking orientated around energy efficiency is advocated by federal ministries and their affiliates (interviews state official 1 and energy actor 2). Secondly, there are other instances where city politicians are keen to present their utilities to the electorate as pioneers of sustainable urban development. Energy managers in urban wastewater utilities report that municipal decisionmakers (in city parliaments and councils or environment committees) expect utility managers to act inter-sectorally. These local politicians want their urban utilities to run flagship projects and practise nexus thinking. There are political majorities in these city councils to run urban utilities in the interest of urban environmental sustainability and not merely in accordance with their statutory obligations and cost-efficiency criteria. Following this lead, some urban wastewater utility managers are seeking to implement nexus-oriented projects to support their city's energy transition policy (interviews operators 1, 2 and 3 and association 2).

Thirdly, wastewater operators might be concerned that active involvement in energy markets could jeopardise their core business of wastewater treatment. Workshop participants 
voiced fears that power grid operators might gain influence over parts of the wastewater treatment process, requiring wastewater utilities to shut down, limit or provide power generation according to the fluctual needs of the power grid. These hesitant observers admit this might not be a real danger today but could be in the future, when power grid operators may have to manage lower capacities of electricity and may be less interested in drawing on the load management services of wastewater utilities (interviews operators 1 and 4).

\section{Urban nexus realities: Experiences of promoting infrastructural co-management}

How are these approaches to the wastewater-energy nexus translating into practice? We discuss in the following section the experiences made to date with the emergent forms of 'external' nexus practices, structured according to the various technical options.

\section{Wastewater to power transmission grid}

The first option is for wastewater utilities to become active in providing flexibility to electricity flows at the large scale of transregional power transmission grids. They may act directly, buying and selling electricity to help balance the needs of the transmission grid (Regelenergiemärkte). However, this requires them to meet tough federal prequalification standards, which are currently under political review (interview energy actor 4). A less risky and more pragmatic way of operating as an integral part of the transmission grid is to contract a market player to organise a pool of small flexibility providers, so-called virtual power plants (interviews operators 8 and 5). This pool of actors can meet the prequalification standards collectively more easily and its members can protect each other from unforeseen or uncontrollable risks (Deutsche Energieagentur, 2014; interview energy actor 4). Participating in balancing markets is regarded as a valuable first step into the energy sector for wastewater operators (interview energy actor 4).

The wastewater company in Kaiserslautern is a pioneer in that it is not contracting an energy trader for pooling electricity for the transmission grid. A subsidiary of Kaiserslautern's multi-utility (Stadtwerk), rather than the wastewater utility itself, is assembling its own pool, including other regional wastewater operators, to prequalify for balancing markets (interview operator 5). This model has enabled facilities of urban and suburban wastewater utilities to be joined into a wastewater-based virtual power plant. Legally, it is this subsidiary and not the wastewater utilities themselves that is enrolled by the operator to deliver energy (interview operator 5).

Experiences of interacting with the transmission grid are not all positive, however. The profit margins in balancing power markets are currently modest, acting as a disincentive (interview association 5). Some utilities are hesitant because they fear having to switch wastewater facilities on and off to meet the needs of the transmission grid (interviews operators 1 and 2). There is evidence that state regulatory authorities are delaying approval processes considerably out of caution (interviews operator 5 and state official 1). Grid operators are drawing on a plethora of regulations on self-provision, storage and feed-in of electricity to act, effectively, as gatekeepers to the market (interviews association 4 and operator 3; BEE, 2015). Wastewater utilities complain that they have to report monthly to grid operators about every single generating facility (interview operator 3), whilst under-staffed grid operators claim to be overwhelmed by the paperwork involved in connecting new local energy generators (interview energy actor 3 ). 


\section{Wastewater and electricity to purified sewage gas and hydrogen}

A second option being currently practised is to feed biogas from sewage sludge or hydrogen from electrolysis into the local gas distribution network and thereby minimise imports of natural gas, a fossil fuel. Sewage gas or hydrogen can readily be purified to natural gas standards before being fed into the network (Schäfer et al., 2015). Significantly in terms of balancing the electricity market, wastewater utilities can refrain from converting sewage gas to electricity - and draw on the grid - at times of high renewable power generation and, conversely, generate their own electricity from stored sewage gas when there is high demand (and a high price) for grid electricity. More than this, new technologies are enabling wastewater utilities to convert surplus electricity (occurring, for instance, during peak generation of wind and solar power) into hydrogen and oxygen by a process of water electrolysis. These power-to-gas technologies could become a key component of urban utilities balancing regional energy markets. In future, the ability to store surplus electricity in this way could open up new nexus practices for wastewater utilities as energy transition actors (interviews association 2 and state official 3).

Two large German wastewater utilities, in Hamburg and Cologne, already feed sewage gas purified to natural gas quality into the regional distribution system. In both cases, local politicians decided to connect their wastewater plant to the gas grid. In Hamburg, making the city's utilities more sustainable through inter-connectivity was a key demand of the Green Party in the governing coalition (interviews operators 2 and 3). By purifying and storing surplus sewage gas in the gas network according to the needs of energy markets, wastewater utilities - as in Hamburg and Cologne - can avoid having to construct expensive storage capacities on site (interview operator 2).

However, wastewater utilities need legal clarity (interview association 2) and less restricted access to profitable business models in surplus energy storage (interview association 4) before they can become effective actors at the sewage gas-electricity nexus. Power-to-gas is posing new regulatory challenges. This applies to tax liabilities and accountability for wastewater utilities that are, by law, not allowed to act beyond their explicit public duties to treat and dispose of wastewater. Using energy generated in the course of wastewater treatment processes is not a problem in this regard, but storing energy generated externally might well be interpreted as exceeding this remit (interview state official 1). Economically, power-to-gas is currently not feasible. National energy policy is unlikely to support cross-sectoral power-to-gas technologies in the coming years, for fear of over-subsidising specific technological solutions (interview state official 2). Physically, feeding gas into the local gas network can be obstructed by the absence of a nearby gas mains (interviews operators 7 and 8). Gas network operators are obliged by law to connect every new biogas facility to the network and construct the gas pipe to the feed-in point at their own cost. In practice, however, the incumbent network operator is often reluctant to do so, owing to the technical and organisational work involved in connecting numerous new providers. Attitudes are changing, though, in acknowledgement that gas feed-in cannot be resisted indefinitely (interview energy actor 5).

\section{Wastewater to heat}

A third nexus option for wastewater utilities is to sell the heat produced at various stages of sewage treatment. Using sewage gas to cogenerate heat and power and feeding these 
into the respective local networks is, thus, a further way of integrating wastewater utilities into energy markets. Surplus heat from the sewage treatment process is already being delivered to district heating systems in many cities (interview operator 4 ).

The main infrastructural condition for this nexus practice is the availability of local heating networks in close proximity to wastewater treatment plants (interviews operators 3 and 4). This is not usually the case, requiring additional funding for the necessary infrastructure connections. Various financing models exist to facilitate this interaction. In one case, the wastewater utility delivers heat for free to other municipal facilities, like schools or swimming pools, in return for the city paying the costs of connecting to the network. In another instance, the public utility operating the heating network pays for transporting the heat (interview operator 7). Currently, only a few wastewater utilities appear to be acting cross-sectorally in the heating market (interview association 1). Intriguingly, the European Commission sets great store on integrating heat produced via wastewater treatment into the urban heating market, arguing that this is a free source of energy that should make this nexus practice highly competitive (interview state official 3).

\section{Wastewater to power distribution grid}

The fourth option - operating in power distribution grids - is not currently operable, but rather a future possibility. In contrast to transmission grids, there exist no balancing markets in power distribution grids to date. To guarantee system balance, distribution grid operators act in specifically defined corridors, strongly regulated in cascades by the federal grid agency (interviews energy actors 1 and 3). In future, flexibility markets are likely to emerge in distribution grids too, bringing with them new business opportunities for local flexibility providers (interview energy actor 2; Fraunhofer IWES and Agora Energiewende, 2015).

Integrating local flexibility providers into regional energy markets, especially at the scale of distribution grids, will require effective smart grids. Digital communication is necessary to enable grid operators to collect data relating to the generation and storage capacity and performance of flexible actors (interviews associations 4 and 5). A further demand to improve market access for flexibility providers is the introduction of financial rewards - in the form of compensation from the grid operator - for the load balancing services performed by wastewater utilities (interviews energy actor 4 and association 3). One way of rewarding flexibility providers currently being discussed in Germany is to make charges for grid use more responsive to real-time demand on the distribution grids (interview association 1). A traffic light system - indicating stress levels from green to red in the electricity distribution grids - could trigger special tariffs for such services (interview association 5). Introducing instruments of this kind to support regional energy markets is a key demand made of German and European energy policy.

\section{Coupling urban infrastructures: The findings interpreted}

What can ongoing practices of integrating energy produced or stored in urban wastewater treatment plants into regional energy markets in Germany tell us about the opportunities and challenges of coupling infrastructures? What is the role of the 'urban' in these ventures? Given the infancy of these new collaborative ventures at the wastewater-energy nexus it is too early to give any definitive assessment of their prospects for the future, but we can draw important observations of a generic nature based on the aspirations of those involved and the experiences they have 
made to date. In structuring these reflections, we seek to address the core themes raised in this special issue: on the materialities, spatialities, temporalities and politics of infrastructure integration.

\section{Materialities of integration}

Seeking synergies between two distinct infrastructure systems is, in the first instance, about understanding the physical contexts and the opportunities and limitations which these present. In the case of the wastewaterenergy nexus, discussed here, two material dimensions are particularly significant: the flows of energy and resources on the one hand and the physical structures used to treat and transport them on the other. In both instances, we have observed how effective integration is dependent to a substantial degree on what we might call material complementarity.

In terms of energy and wastewater flows, this requires detailed knowledge about the kinds of energy (electricity, different types of gas, heating) that can be produced from particular compositions of wastewater (e.g. raw sewage, sewage sludge) at certain stages in the wastewater treatment process. It also requires understanding the physical processes at play in an energy network, which vary hugely depending on whether it transports heat, gas or diverse voltages of electricity. These physical differences are particularly apparent regarding storage. The physical challenges of storing electricity with available technology are generating creative responses involving its transformation into other energy forms, such as gas or heat. But each of these energy transformations raises fresh issues of material compatibility, for instance over how much gas derived from surplus electricity can be fed into a local gas network. Interestingly, storage can work both ways, our findings reveal: not only can wastewater utilities take up excess electricity and store it in gas form when the grid demands, but the gas network can take up surplus gas produced in wastewater treatment.

In terms of the physical structures used to treat and transport energy or wastewater, the study has reiterated the importance of material connectivity between two different infrastructure systems. If the wastewater treatment plant is not connected to the gas network then feeding surplus gas into this network is not an option, unless a connection is built for the purpose. Enabling these fine-tuned connections requires smart technologies capable of measuring, modelling and steering these flows of energy and resources and coupling these infrastructure networks. Smart grids, however, are only in their infancy in Germany and have not as yet had a significant bearing on initiatives to connect wastewater to energy systems.

If, through this analysis, we are deliberately according a degree of agency to the various materialities involved in coupling infrastructure systems, we do this in full acknowledgement that none of them can ever act alone but always in conjunction with other material and, above all, non-material elements. How they get enrolled in placespecific socio-technical configurations and, conversely, how they themselves frame processes of dis- and reassembling - for instance of wastewater and energy systems - is critical to understanding the prospects for infrastructure integration.

\section{Spatialities of integration}

Using municipal wastewater utilities to relieve pressure on regional or national energy networks has revealed, secondly, the importance of spatial alignments and placespecific contexts to practices at the wastewater-energy nexus. Essentially, the various modes of infrastructural integration described here are all about connecting renewable energy generated in cities (i.e. 
where wastewater is collected) to energy networks that vary in geographical range from the local (e.g. district heating), via the regional (e.g. power distribution grid) to the national and trans-national (e.g. power transmission grid). Cities in Germany are beginning to realise how their own wastewater utilities can make an environmentally significant and strategically important contribution to the energy transition, in particular in coping with intermittent renewable energy inputs to the power grid. Although supported by federal and state funding, these initiatives are essentially municipal in origin and character. It is, as we have noted, often urban politicians, rather than the wastewater utilities themselves, that are the prime drivers behind the schemes, keen to see their own utilities playing a pioneering role in low carbon, non-nuclear energy futures.

The local embeddedness of renewables calls for local responses to electricity load management. Cities are using their proximity to areas of renewable energy generation to set themselves up as such flexibility providers. What is spatially significant to these urban initiatives is that they are not about making the city itself more self-sufficient or renewable in its energy generation, but about connecting the energy produced or stored in the city to networks operating at regional and transregional scales. The reconfiguration processes this demands are not merely socio-material, as we argued earlier, but also distinctly sociospatial. Relations between the city and the spaces beyond which its wastewater utilities are serving - albeit often indirectly - are being reordered, as expressed in new business alliances, inter-municipal collaboration and material flows. This is revealing some interscalar synergies (e.g. between municipal utilities and the national association for energy and water) on the one hand, but some scalar mismatches (e.g. between localised wastewater treatment plants and regionally oriented grid operators) on the other.

\section{Temporalities of integration}

The future role for wastewater utilities as flexibility providers depends, thirdly, on them being able to help balance out the peaks and troughs of (renewable) energy supply and demand not only in certain places, but also at certain times. Flexibility provision is all about balancing out supply and demand curves for electricity at any time of day or year, given the difficulties of storage. In the case of wastewater utilities, this requires aligning wastewater treatment processes with power generation and consumption processes in real time. This is a highly complex task, challenging even when smart technologies are installed (which is often not the case). Disjointed temporalities can also emerge on longer timescales. Nexus solutions need to consider the investment cycles of both infrastructure systems - for wastewater and energy. Beyond this, wastewater utilities are being asked to introduce experimental forms of interaction with energy systems today without being at all certain of what the future will bring. If their role as flexibility providers is to transcend this small-scale, experimental phase, they will need to align their long-term investment programmes with more reliable prognoses for their prospects in the energy market. This is not made any easier by the striking asymmetry in system dynamics between the energy and wastewater sectors. Whilst the energy sector is undergoing a prolonged and intensive period of transition, no similar 'wastewater transition' can be detected in Germany. Wastewater utilities possess, however, significant potential to support the development of new energy storage technologies, such as power-to-gas. Although constrained by the need to ensure affordable wastewater tariffs, they have access to a secure source of funding that does not demand a rapid return on investments. This makes them well-placed financially to invest in energy storage technologies at a time 
when private investors are, as yet, reluctant to commit themselves.

\section{Politics of integration}

Our study reveals, fourthly, that infrastructure integration is about much more than achieving a new techno-managerial fix. The initiatives of municipal wastewater utilities to act in regional energy markets may be couched in the rhetoric of meeting climate protection targets and supporting Germany's energy transition, but they are essentially political in that they are advancing particular interests at the expense of others. We can therefore talk of this nexus issue becoming 'politicised' in practice. Although we did not identify any publicly voiced opposition to what the wastewater utilities are trying to do, we uncovered plenty of evidence of behind-the-scenes resistance. Above all, the incumbent operators of power distribution grids - but also of gas networks - are anything but enamoured by what they regard as the intrusion of additional newcomers in an increasingly complex energy market for which they are responsible. Although legally obliged to treat the wastewater utilities as any other energy contributor, they are in many instances using their gatekeeper roles to delay and complicate market entry. The wastewater utilities are responding by enrolling the support of their respective cities (for instance, in acquiring grid concessions) and entering into alliances with other local wastewater utilities or energy utilities. Here, we note the huge significance in Germany of the municipal ownership of many utilities. City politicians are often keen to use their ownership of infrastructures and utilities to play their own, distinctive role in Germany's energy transition, balancing the grids and thereby promoting renewables, as well as strengthening local resilience against intermittent power supply. Where the wastewater utility and the local power distribution grid are owned by the same city, the political will to cooperate is far more likely to override commercial opposition or managerial scepticism than elsewhere.

Many of the difficulties encountered by the wastewater utilities emanate from unfavourable institutional conditions - themselves a product and reflection of inadequate political will at the national level. The regulations governing how wastewater utilities should operate and how open energy markets should function are proving currently highly restrictive to the utilities' aspirations to provide flexibility for energy networks. On the one hand, they are bound to the nonprofit operation of statutory tasks restricted to treating and disposing of wastewater, which is - at the very least - creating uncertainty for the wastewater utility as to how far they can go in marketing energy. On the other hand, entry into energy markets is restrained by various disincentives, such as the prequalification standards required for acting as flexibility providers in the transmission grid. Regulations in the energy sector still favour, in general, grid expansion over the integration of flexibility options. So long as the political will to re-prioritise is not forthcoming, wastewater utilities continue to campaign for better incentives to work within the existing system, such as compensation payments for helping balance regional power grids, as our stakeholder workshops have revealed. In the longer term, they are setting their sights on a more favourable institutional framework for inter-sectoral activities, targeting reforms to federal legislation on grid access, energy markets and smart grids.

The political contestation over the wastewater-energy nexus - these examples tell us - cannot be reduced to a straightforward dispute between incumbents and newcomers. Political differences over regional energy markets and the role of urban wastewater utilities in them are multi-dimensional. Whether challenging the conventional bounds 
of energy and wastewater systems, the territorial restrictions of urban utilities or the investment priorities of energy grids, the emergence of urban wastewater operators as new actors of regional energy markets for electricity, gas and heating is prompting the reappraisal of fundamental tenets of energy and wastewater policy in Germany. This is politicised nexus thinking in practice.

\section{Conclusion}

This article has set out to deconstruct the notion of urban nexus as some idealised vision of optimal integration and win-win solutions of universal benefit. Rather than denying the validity of cross-sectoral collaboration as a potential way of achieving more sustainable cities, it subjected ongoing experiences in integrating two infrastructure systems to critical scrutiny. Taking the case of municipal wastewater utilities in Germany trying to act as flexible energy providers, we were interested in discovering how the realities of work at the wastewater-energy nexus are living up to the aspirations these actors have about their future role in regional energy markets. Their experiences can, we posited at the start, provide fresh insight into the socio-materialities, multiple geographies, uneven temporalities and contested politics involved in nexus practices and contribute, thereby, to the burgeoning literature on urban infrastructures in transition. In addition, they can draw attention to the potentially crucial role for cities and their urban utilities in balancing the volatility of wind and solar power and thereby advancing renewables as sources of baseload electricity.

In a first step, we summarised the policy frameworks and technical options for integrating wastewater treatment and energy networks in Germany today. We analysed how certain municipal wastewater utilities and city councils are aspiring to fulfil a role in regional energy markets by providing one or more of these flexibility options. How realistic these nexus imaginaries are in practice was then assessed in terms of the experiences made by wastewater utilities in pursuing their objectives of infrastructure integration at the wastewater-energy nexus. Each of the technical options for flexibility providers in Germany's energy markets has been implemented to some degree. Some - such as balancing the power transmission grid - are economically feasible for the wastewater utility under current market conditions; others like power-to-gas solutions - need additional financial incentives to justify investment.

However, their application by the wastewater utilities confronts significant challenges of a largely non-technical nature. These we categorised - in line with this special issue in terms of the materialities, spatialities, temporalities and politics of infrastructure integration. We demonstrated how dependent this wastewater-energy nexus is on the material complementarity of not only flows of energy and wastewater but also the physical structures used to treat and transport them. We illustrated the multiple geographies at play in reconfiguring urban wastewater systems so that they can interact effectively with regional and national energy markets. We highlighted also the importance of aligning a variety of temporalities ranging from realtime energy flows to long-term infrastructure investment plans. We argued, finally, how political this venture is, since it is effectively reordering power relations between incumbents and newcomers as well as between energy and wastewater sectors, as evidenced by the strong resistance by the former and alliance-building by the latter. Each of these findings we see as a contribution to a more robust socio-technical understanding of the political geographies involved in reconfiguring urban infrastructures along more crosssectoral, nexus-oriented lines.

For urban studies, the article highlights several promising avenues for future research 
on urban dimensions of the nexus. It demonstrates why it is critical to study cross-sectoral urban metabolism from a socio-material perspective, revealing interplay between energy and water as dynamic relations between human and non-human elements of the urban condition. It reiterates the importance of employing a relational understanding of the 'urban', showing how the city can be a political actor of energy transition, a place where infrastructures interact, a niche for technological innovation and/or an owner of a municipal utility advancing innovation technologies. Finally, it encourages researchers to look beyond the bounds of the city to explore the socio-material dimensions to their relations across multiple scales and with the regions on which they depend to work the water-energy-food nexus.

\section{Declaration of conflicting interests}

The author(s) declared no potential conflicts of interest with respect to the research, authorship, and/or publication of this article.

\section{Funding}

The author(s) disclosed receipt of the following financial support for the research, authorship, and/or publication of this article: The research was conducted in the context of an interdisciplinary project (arrivee) funded by the German Ministry of Education and Research (BMBF) under its programme 'Energy-efficient and Resource-saving Water Management - ERWAS'.

\section{References}

Agora Energiewende (2017) Energiewende und Dezentralität. $\mathrm{Zu}$ den Grundlagen einer politisierten Debatte. Available at: https://www. agora-energiewende.de/fileadmin/Projekte/2016/ Dezentralitaet/Agora_Dezentralitaet_WEB.pdf (accessed 2 October 2017).

Allouche J, Middleton C and Gyawali D (2015) Technical veil, hidden politics: Interrogating the power linkages behind the nexus. Water Alternatives 8: 610-626.
Brondzio ES, O’Brien K, Bai X, et al. (2015) Re-conceptualizing the Anthropocene: A call for collaboration. Global Environmental Change 39: 318-327.

Bulkeley H, Broto VC, Hodson M, et al. (2011) Cities and Low Carbon Transitions. London and New York: Routledge.

Bundesverband Erneuerbare Energien (BEE) (2015) Strommarkt-Flexibilisierung - Hemmnisse und Lösungskonzepte. Available at: https://www.bee-ev.de/fileadmin/Publikationen/ Studien/20150216BEE_Strommarkt_Flexibilisie rung.pdf (accessed 13 January 2017).

Cairns R and Krzywoszynska A (2016) Anatomy of a buzzword: The emergence of 'the waterenergy-food nexus' in UK natural resource debates. Environmental Science \& Policy 64: 164-170.

Chen B and Chen S (2016) Urban energy-water nexus: A network perspective. Applied Energy 184: 905-914

Chen B and Lu Y (2015) Urban nexus: A new paradigm for urban studies. Ecological Modelling 318: 5-7.

Coenen L, Benneworth P and Truffer B (2012) Toward a spatial perspective on sustainability transitions. Research Policy 41: 968-979.

Deutsche Energieagentur (2014) Dena-Studie Systemdienstleistungen 2030. Sicherheit und Zuverlässigkeit einer Stromversorgung mit hohem Anteil erneuerbarer Energien. Available at: https://shop.dena.de/fileadmin/denashop/med ia/Downloads_Dateien/esd/9094_dena-Studie _Systemdienstleistungen_2030.pdf (accessed 13 January 2017).

Deutsche Energieagentur (2017) Optimierter Einsatz von Speichern für Netz- und Marktanwendungen in der Stromversorgung. Available at: https://shop.dena.de/fileadmin/denashop/ media/Downloads_Dateien/esd/9191_dena Netzflexstudie.pdf (accessed 2 October 2017).

Fraunhofer IWES and Agora Energiewende (2015) The European power system in 2030: Flexibility challenges and integration benefits. An analysis with a focus on the pentalateral energy forum region. Available at: https:// www.agora-energiewende.de/fileadmin/Projek te/2014/Ein-flexibler-Strommarkt-2030/Agora_ European_Flexibility_Challenges_Integration_ 
Benefits_WEB_Rev1.pdf (accessed 13 January 2017).

Gandy M (2004) Rethinking urban metabolism: Water, space and the modern city. City 8: 363-379.

Graham S and Marvin S (2001) Splintering Urbanism: Networked Infrastructures, Technological Mobilities and the Urban Condition. London and New York: Routledge.

Hake JF, Schlör H, Schürmann K, et al. (2016) Ethics, sustainability and the water, energy, food nexus approach - a new integrated assessment of urban systems. Energy Procedia 88: 236-242.

Hodson M and Marvin S (2010) Urbanism in the Anthropocene: Ecological urbanism or premium ecological enclaves? City 14(3): 298-313.

Hussey K and Pittock J (2012) The energy-water nexus: Managing the links between energy and water for a sustainable future. Ecology and Society 17(1): 31.

Jensen KM (2013) Viewpoint - Swimming against the current: Questioning development policy and practice. Water Alternatives 6: 276-283.

Kaika M and Swyngedouw E (2000) Fetishizing the modern city: The phantasmagoria of urban technological networks. International Journal of Urban and Regional Research 24: 120-138.

Luque A (2014) The smart grid and the interface between energy, ICT and the city. In: Dixon T, Eames M, Hunt M, et al (eds) Urban Retrofitting for Sustainability. London: Earthscan, pp. 159-173.

Meadowcroft J (2009) What about the politics? Sustainable development, transition management, and long term energy transitions. Policy Science 42: 323-340.

Melosi M (2000) The Sanitary City: Urban Infrastructure in America from Colonial Times to the Present. Baltimore, MD and London: The John Hopkins University Press.

Monstadt J (2009) Conceptualizing the political ecology of urban infrastructures: Insights from technology and urban studies. Environment and Planning A 40: 1924-1942.

Moss T, Naumann M and Krause K (2017) Turning wastewater into energy: Challenges of reconfiguring regional infrastructures in the Berlin-Brandenburg region. Local Environment 22(3): 269-285.
Nair S, George B, Malano HM, et al. (2014) Water-energy-greenhouse gas nexus or urban water systems: Review of concepts, state-ofart and methods. Resources, Conservation and Recycling 89: 1-10.

Quitzow L, Canzler W, Grundmann P, et al. (2016) The German Energiewende - What's happening? Introducing the special issue. Utilities Policy 41: 163-171.

Rutherford J and Coutard O (2014) Urban energy transitions: Places, processes and politics of socio-technical change. Urban Studies 51(7): 1353-1377.

Schäfer M, Gretzschel O, Knerr H, et al. (2015) Die Kläranlage als Regelbaustein im Energienetz - power-to-gas-to-power. wwt - Wasserwirtschaft Wassertechnik 6: 27-29.

Scott CA, Pierce SA, Pasqualetti MJ, et al. (2011) Policy and institutional dimensions of the water-energy nexus. Energy Policy 39(10): 6622-6630.

Seidl H (2016) In der Wasserwirtschaft sehe ich großes Potential. Zeitung für kommunale Wirtschaft 7: 2. Available at: https://www.dena .de/fileadmin/dena/Dokumente/Meldungen/Zf K-dena-Demand-Side-Management-Hannes-Se idl-07-16.pdf (accessed 13 January 2017).

Stein C, Barron J and Moss T (2014) Governance of the Nexus: From Buzz Words to a Strategic Action Perspective. Brighton: The Nexus Network.

Stirling A (2014) Transforming power: Social science and the politics of energy choices. Energy Research \& Social Science 1: 83-95.

Umweltbundesamt (ed.) (2016) Strommarktdesign der Zukunft. Available at: https://www .umweltbundesamt.de/sites/default/files/medien/ 378/publikationen/climate_change_20_2015_stro mmarktdesign_der_zukunft_0.pdf (accessed 13 January 2017).

Venkatesch G, Chan A and Brattebrø H (2014) Understanding the water-energy-carbon nexus in urban water utilities: Comparison of four city case studies and the relevant influencing factors. Energy 75: 153-166.

Walker RV, Beck MB, Hall JW, et al. (2014) The energy-water-food nexus: Strategic analysis of technologies for transforming the urban metabolism. Journal of Environmental Management 141: 104-115. 
Williams J, Bouzarovski S and Swyngedouw E (2014) Politicising the Nexus: Nexus Technologies, Urban Circulation, and the Coproduction of Water-energy. Brighton: The Nexus Network.

World Economic Forum (2011) Water Security:

The Water-Food-Energy-Climate Nexus. Washington, DC, Covelo, CA and London: Island Press.

\section{Appendix A I}

\section{List of interviews}

Operator 1: Berliner Wasserbetriebe, 6 October 2015

Operator 2: HAMBURG WASSER, 7 January 2016

Operator 3: Stadtentwässerungsbetriebe Köln AöR (Cologne), 26 February 2016

Operator 4: Wirtschaftsbetrieb Mainz AöR, 11 September 2015

Operator 5: Stadtentwässerung

Kaiserslautern, 9 September 2015

Operator 6: hanseWasser Bremen $\mathrm{GmbH}, 8$ January 2016

Operator 7: Wupperverband, 25 June 2015

Operator 8: Emschergenossenschaft/ Lippeverband, 18 January 2016

Association 1: Verband Kommunaler Unternehmen, 19 August 2015
Association 2: Bayrischer Gemeindetag, 18 October 2016

Association 3: Bundesverband Erneuerbare Energien, 8 February 2016

Association 4: Deutsche Vereinigung für Wasser, Abwasser und Abfall, 2 April 2016

Association 5: Bundesverband der Energieund Wasserwirtschaft, 27 August 2015

State official 1: environment ministry Rhineland Palatinate, 26 November 2015

State official 2: German Federal Ministry for Economy and Energy, 22 September 2015

State official 3: EU Commission Directorate General Energy, 13 July 2016

Energy actor 1: distribution power grid operator Pfalzwerke, 7 September 2015

Energy actor 2: energy agency North-Rhine Westphalia, 3 February 2016

Energy actor 3: local multi-utility (Stadtwerke Radevormwald), 28 September 2015

Energy actor 4: power trader (Clens), 22 March 2016

Energy actor 5: distribution gas grid operator, 19 November 2015 